\title{
Bentuk preparasi akhiran servikal mahkota porcelain fused to metal mempengaruhi insidensi gingivitis pada gigi insisivus sentralis rahang atas
} Preparation shape of cervical edge of porcelain fused to metal crown affect incidence of gingivitis at maxillary central incisive teeth

\author{
${ }^{1}$ Abd. Karim, ${ }^{2}$ Moh. Dharmautama, ${ }^{2}$ Edy Machmud \\ ${ }^{1}$ PPDGS Prostodonsia dan SMF Prostodonsia RS Wahidin Sudirohusodo \\ ${ }^{2}$ Bagian Prosthodonsia, Fakultas Kedokteran Gigi Universitas Hasanuddin \\ Makassar, Indonesia
}

\begin{abstract}
The selection of cervical edge form of porcelain fused to metal (PFM) crown is very important because it is associated with the incidence of gingivitis. Improper types of cervical edge may cause a gap at the edge; which is a good place for the growth and development of dental plaque bacteria that play a major role in the occurrence of inflammation. This study aims to determine the effect of the cervical edge preparation shape of PFM crown against bacterial plaque adhesion and tissue inflammation supporting abutments, as well as to determine the best shape of the cervical edge preparation for PFM crown restoration. This Clinical experimental research with time series design is performed to 3 groups of cervical edge preparation design, i.e. shoulder, bevel shoulder and deep chamfer. Sample of 15 people divided equally into the 3 groups. Examination of the clinical signs of gingivitis (gingival discoloration, bleeding on probing, and pocket depth) and the number of bacterial colonies were performed before tooth preparation; 1, 7, and 21 days after insertion. The data were processed statistically by ANOVA. The results showed the form shoulder bevel edge gives the most noticeable impact to gingivitis than other types.
\end{abstract}

Keywords: porcelain fused to metal, gingivitis, cervical edge preparation

\begin{abstract}
ABSTRAK
Pemilihan bentuk preparasi akhiran tepi servikal pada mahkota porcelain fused to metal (PFM) sangat penting karena berkaitan dengan kejadian gingivitis. Pemilihan bentuk preparasi yang tidak tepat dapat menyebabkan celah pada tepi yang merupakan tempat yang baik bagi pertumbuhan dan perkembangan bakteri plak gigi yang berperan utama pada terjadinya keradangan. Penelitian ini bertujuan untuk mengetahui pengaruh bentuk preparasi akhiran tepi servikal pada mahkota PFM terhadap perlekatan bakteri plak dan inflamasi jaringan pendukung gigi penyangga, serta untuk mengetahui bentuk preparasi akhiran tepi servikal terbaik bagi restorasi mahkota PFM. Penelitian eksperimen klinis dengan rancangan time series dilakukan terhadap 3 kelompok desain preparasi tepi servikal, yaitu shoulder, bevel shoulder, dan deep chamfer. Sampel sebanyak 15 orang dibagi rata ke dalam 3 kelompok tadi. Pemeriksaan tandatanda klinis gingivitis (perubahan warna gingiva, perdarahan saat probing, dan kedalaman poket) dan jumlah koloni bakteri dilakukan sebelum preparasi gigi, serta 1, 7, dan 21 hari setelah insersi mahkota PFM. Data yang diperoleh kemudian diolah secara statistik dengan uji ANOVA. Hasil penelitian menunjukkan bentuk preparasi akhiran tepi bevel shoulder memberikan dampak yang paling nyata terhadap kejadian gingivitis dibandingkan jenis desain shoulder dan deep chamfer.
\end{abstract}

Kata kunci: porcelain fused to metal, gingivitis, akhiran preparasi servikal

Koresponden: Abdul Karim. E-mail: drg.karim@gmail.com

\section{PENDAHULUAN}

Pemakaian gigitiruan cekat untuk merestorasi gigi alami yang rusak atau hilang semakin populer saat ini di masyarakat, karena bentuknya lebih kecil, sederhana, nyaman digunakan, sifat estetikanya, dan dapat menambah rasa percaya diri pemakainya jika dibandingkan dengan gigitiruan lepasan. ${ }^{1}$ Namun banyak kegagalan yang terjadi pada pemasangan gigitiruan cekat yang berhubungan dengan bentuk akhiran servikalnya. Banyak penelitian sebelumnya melaporkan bentuk akhiran servikal sangat terkait dengan kondisi jaringan periodontal pascainsersi. ${ }^{2-4}$

Pemilihan bentuk akhiran preparasi servikal yang tidak akurat dapat menyebabkan celah antara tepi preparasi dengan tepi restorasi, sehingga terjadi peradangan pada jaringan gingival. ${ }^{1,5,6}$ Peradangan pada gingiva dapat disebabkan oleh penggunaan bahan restorasi yang tidak dapat diterima oleh imun tubuh. Salah satu bahan yang diterima oleh tubuh atau bersifat biokompatibel adalah porselen, karena merupakan bahan restorasi yang mempunyai nilai estetika yang menyerupai gigi alami dan bersifat biokompatibel terhadap jaringan di dalam rongga mulut. ${ }^{7-9}$

Restorasi yang menggunakan bahan porselen, seperti mahkota porcelain fused to metal (PFM), membutuhkan ketebalan bahan yang cukup agar bagian tepi bukalnya tidak mudah retak atau patah. 
Untuk maksud tersebut, desain akhiran servikal yang dianjurkan adalah shoulder, bevel shoulder dan deep chamfer.Pemilihan restorasi tersebut dilakukan sebab dibutuhkan faktor estetika yang optimal untuk restorasi gigi anterior dan sifat biokompatibel bahan porselen agar tidak memberi reaksi alergi terhadap mukosa; sedangkan pada aspek lingual, preparasi tepi servikalnya berbentuk chamfer karena terbuat dari bahan logam..$^{1,10,11}$

Bahan restorasi ditentukan oleh bentuk akhiran preparasi. Beberapa penelitian melaporkan bahwa celah tepi servikal merupakan tempat yang baik bagi pertumbuhan dan perkembangan bakteri plak gigi yang berperanan penting terhadap terjadinya peradangan pada jaringan periodontal. ${ }^{12-15}$ Telah banyak dibahas tentang pengaruh bentuk preparasi terhadap terjadinya peradangan pada gingiva, baik penempatan maupun bentuk akhiran servikal yang sangat berpengaruh terhadap terjadinya gingivitis. ${ }^{15}$

Hasil riset tentang lokasi akhiran servikal yang menyebabkan terjadinya gingivitis masih belum ada kejelasan. Di satu sisi banyak peneliti menyatakan bahwa penempatan akhiran servikal di subgingiva banyak berkontribusi terhadap terjadinya gingivitis. Akan tetapi di sisi lain dilaporkan bahwa penempatan akhiran servikal yang di supragingiva juga dapat menyebabkan reaksi gingivitis tergantung pada ada tidaknya plak gigi yang dapat menempel pada tepi servikal restorasi.

Keberhasilan perawatan gigitiruan cekat sangat bergantung kepada kondisi adaptasi tepi restorasi terhadap tepi preparasi gigi penyangga. Apabila ada celah diantaranya hal ini merupakan tempat bagi mikroorganisme untuk tumbuh dan berkembangbiak membentuk koloni. Koloni yang semakin banyak jumlahnya sangat mempengaruhi tingkat keparahan gingivitis. ${ }^{13-15}$

Saatinirestorasi PFM masih merupakan pilihan, karena selain masih dibutuhkan kekuatan logam, harganya terjangkau secara luas oleh masyarakat. ${ }^{13,15}$ Jenis bahan restorasi PFM mempunyai keuntungan jika dibandingkan dengan all porcelain, sehingga pemilihannya harus memperhatikan indikasi kasus, kondisi kesehatan mulut pasien dan faktor ekonomi.

Berdasarkan uraian tersebut di atas, maka perlu dilakukan penelitian untuk mengetahui pengaruh bentuk akhiran preparasi servikal mahkota PFM yang tepat untuk mencegah terjadinya gingivitis

\section{BAHAN DAN METODE}

Penelitian ini dilaksanakan di Rumah Sakit Gigi dan Mulut Fakultas Kedokteran Gigi Universitas Hasanuddin, RSUP dr. Wahidin Sudirohusodo Makassar untuk preparasi dan pemeriksaan tanda klinis gingivitis, serta pengambilan kultur bakteri. Pembuatan restorasi PFM dilakukan diJeruk Dental Laboraratory, Bandung. Penelitian dilakukan pada bulan Juli sampai dengan September 2012.

Populasi penelitian adalah pengunjung RSGM FKG Unhas, RSUP dr. Wahidin Sudirohusodo dan dokter gigi praktek swasta di Makassar yang berusia 20-30 tahun. Subjek penelitian adalah pengunjung dengan indikasi pembuatan gigitiruan cekat pada gigi insisivus sentralis rahang atas yang dibuatkan gigitiruan cekat.

Kriteria inklusi adalah berumur 20-30 tahun, gigi insisivus sentralis rahang atas yang mengalami karies yang tidak dapat direstorasi dengan komposit, tidak ada kelainan periapikal, kebersihan rongga mulut baik, tidak menderita penyakit sistemik, tidak mengkonsumsi antibiotik dalam 3 bulan terakhir, tidak ada perdarahan pada gingiva, dan bersedia ikut dalam penelitian dengan menandatangani informed consent. Sedangkan kriteria eksklusi adalah gigi yang akan dirawat endodontik, gingiva berdarah saat probing, ada true pocket, dan tidak bersedia mengikuti prosedur penelitian.

Mahkota PFM adalah mahkota tiruan untuk mengganti jaringan gigi yang hilang; pada penelitian ini terbuat dari dua bahan restorasi, yaitu logam nikelkromium dan pelapis estetik dari bahan porselen alumina. Bentuk akhiran preparasi servikal adalah bentuk preparasi yang dibuat pada bagian servikal gigiagardiperoleh adaptasi yang baik antara servikal restorasi dengan tepi servikal gigi preparasi. Pada penelitian ini bentuk akhiran preparasi servikal yang dibuat adalah deep chamfer, bevel shoulder dan shoulder.

Plak gigi adalah suatu lapisan tipis yang melekat pada permukaan gigi atau restorasi, sebagai tempat bakteri berkolonisasi dan berkembang biak. Dalam penelitian ini plak adalah lapisan tipis yang diambil dari bagian servikal restorasi PFM yang berhadapan dengan tepi gingiva, dengan menggunakan kultursel. Gingivitis adalah peradangan jaringan gingiva, yang ditandai dengan perdarahan gingiva saat probing dan perubahan kedalaman poket periodontal.

Penelitian eksperimental klinis ini dilakukan dengan rancangan time series terhadap 3 kelompok perlakuan pembuatan desain preparasi tepi servikal, yaitu kelompok bentukakhiran preparasi tepi servikal shoulder, bevel shoulder, dan deep chamfer. Sampel sebanyak 15 orang kemudian dibagi ke dalam 3 kelompok tadi, sehingga masing-masing kelompok terdiri atas 5 subjek penelitian.

Sebelum preparasi, semua sampel diberikan penyuluhantentang menjaga kebersihan mulut pasca penggunaan gigitiruan cekatnya, penjelasan tentang 
prosedur penelitian, dan dilakukan pembersihan kalkulus. Seluruh tahapan penelitian disampaikan ke subjeknya dan diminta menandatangani informed consent jika menyetujuinya. Pemeriksaan tandatanda klinis gingivitis (perubahan warna gingiva, perdarahan saat probing, dan kedalaman poket) serta pemeriksaan jumlah koloni bakteri dilakukan sebelum preparasi gigi, serta pada hari ke-1, 7, dan 21 pasca insersi gigitiruan cekat. Gigitiruan cekat yang digunakan adalah mahkota PFM. Data yang diperoleh kemudian diolah secara statistik dengan menggunakan uji ANOVA.

\section{HASIL}

Gambar 1 menunjuk bahwa parameter gingivitis yang diukur meliputi perubahan warna gingiva, kedalaman poket, dan pendarahan gingiva secara nyata lebih tinggi kejadiannya pada pasien dengan bentuk akhiran preparasi servikal bevel shoulder dibandingkan dengan penggunaan deep chamfer dan shoulder. Bentuk akhiran preparasi bevel shoulder memberikan dampak paling nyata terhadap kejadian gingivitis dibandingkan jenis desain lainnya (Tabel 1),yang ditunjukkanpadahasilpemeriksaan pengaruh bentuk akhiran servikal terhadap kejadian gingivitis, terlihat perbedaan hasil pengukuran yang signifikan antara bentuk akhiran preparasi servikal shoulder, bevel shoulder dan deep chamfer $(\mathrm{p}<0,05)$.

Pada gambar 2 terlihat perubahan warna gingiva pada pasien yang menggunakan bahan restorasi PFM mulai nampak pada hari ke-7 pemakaian dan semakin meningkat perubahan warnanya di hari ke21. Adapun bentuk akhiran preparasi servikal yang paling berpengaruh terhadap kejadian perubahan warna tersebut adalah bevel shoulder.

Pada Gambar 3, dinyatakan bahwa kedalaman poket pada pasien yang restorasinya menggunakan bahan PFM mulai terlihat pada hari ke-7 pemakaian dan semakin meningkat di hari ke-21. Adapun jenis bentuk preparasi servikal restorasi yang paling

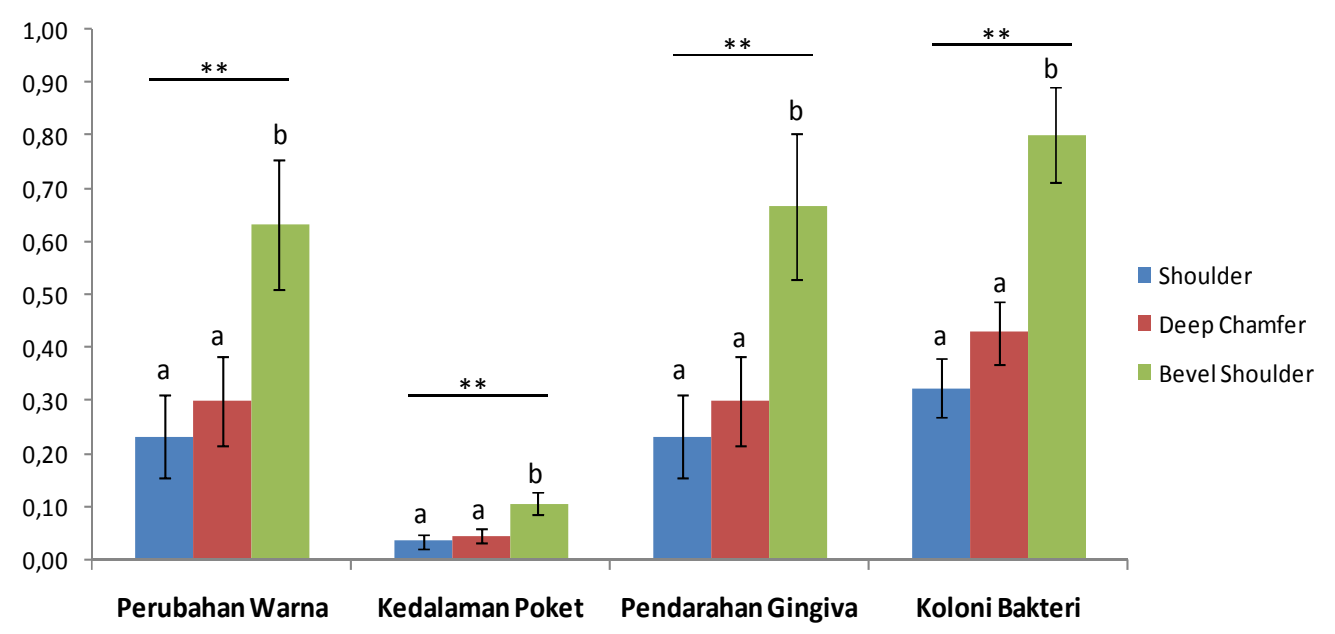

Gambar 1 Grafik batang yang menunjukkan pengaruh bentuk akhiran preparasi servikal terhadap tanda-tanda gingivitis dan peningkatan jumlah koloni bakteri pasca insersi

Tabel 1 Hasil pemeriksaan pengaruh bentuk akhiran preparasi servikal terhadap terjadinya gingivitis.

\begin{tabular}{|c|c|c|c|c|c|c|}
\hline \multirow[t]{2}{*}{$\begin{array}{c}\text { (I) } \\
\text { Bentuk preparasi }\end{array}$} & \multirow[t]{2}{*}{$\begin{array}{c}(\mathrm{J}) \\
\text { BentukPreparasi }\end{array}$} & \multirow{2}{*}{$\begin{array}{c}\text { Mean } \\
\text { difference (I-J) } \\
\text { Lower bound }\end{array}$} & \multirow{2}{*}{$\begin{array}{c}\text { Std. Error } \\
\text { Upper bound }\end{array}$} & \multirow{2}{*}{$\begin{array}{c}\text { Sig. } \\
\text { Lower bound }\end{array}$} & \multicolumn{2}{|c|}{ 95\% Confidence interval } \\
\hline & & & & & Upper bound & Lower bound \\
\hline \multicolumn{7}{|l|}{ Perubahan warna } \\
\hline \multirow{2}{*}{ Bevel Shoulder } & Shoulder & $0,4000(*)$ & 0,13412 & 0,004 & 0,1333 & 0,6667 \\
\hline & Deep Chamfer & $0,3333(*)$ & & 0,015 & 0,0666 & 0,6001 \\
\hline \multicolumn{7}{|l|}{ Kedalaman poket } \\
\hline \multirow{2}{*}{ Bevel Shoulder } & Shoulder & $0,0700(*)$ & 0,02309 & 0,003 & 0,0241 & 0,1159 \\
\hline & Deep Chamfer & $0,0600(*)$ & 0,02309 & 0,011 & 0,0141 & 0,1059 \\
\hline \multicolumn{7}{|c|}{ Pendarahan gingiva } \\
\hline \multirow{2}{*}{ Bevel Shoulder } & Shoulder & $0,4333(*)$ & 0,14365 & 0,003 & 0,1477 & 0,7190 \\
\hline & Deep Chamfer & $0,3667(*)$ & 0,14365 & 0,013 & 0,0810 & 0,6523 \\
\hline \multicolumn{7}{|l|}{ Koloni bakteri } \\
\hline \multirow[t]{2}{*}{ Bevel Shoulder } & Shoulder & $0,4763(*)$ & 0,10101 & 0,000 & 0,2755 & 0,6772 \\
\hline & Deep Chamfer & $0,3717(*)$ & 0,10101 & 0000 & 0,1708 & 0,5725 \\
\hline
\end{tabular}


berpengaruh terhadap peningkatan kedalaman poket adalah bevel shoulder.

Pada grafik gambar 4 terlihat bahwa pendarahan gingiva pada penderita yang menggunakan bahan restorasi PFM mulai nampak pada hari ke-7 pasca pemakaian dan semakin meningkat kejadiannya di hari ke-21. Bentuk akhiran preparasi tepi servikal yang paling berpengaruh meningkatkan pendarahan gingiva adalah bentuk bevel shoulder.

Adapun jumlah koloni bakteri pada sampel yang menggunakan bentuk akhiran preparasi servikal pada restorasi PFM mulai terlihat sejak hari pertama, dan makin meningkatjumlahnya seiring dengan lamanya pemakaian (Gambar 5). Bentuk akhiran servikal yang paling berpengaruh meningkatkan jumlah koloni bakteri pada gingiva adalah bevel shoulder.

\section{PEMBAHASAN}

Bentukakhiran preparasi servikal shoulder dapat menyediakan ketebalan yang cukup bagi porselen di bagian fasial. Pengambilan jaringan yang cukup di bagian servikal membuat para tekniker lebih mudah membentuk pola malam, karena batas preparasi lebih tajam dan lebih tegas. Hasil preparasi yang jelas dan tegas membuat cetakan dan die menjadi akurat. Model die yang akurat membuat hasil restorasi akan akurat pula. Selain itu dengan pengambilan jaringan yang lebih banyak di bagian servikal membuat hasil restorasi di bagian servikal restorasi mendapatkan ketebalan yang cukup. Ketebalan yang cukup pada bagian servikal dapat menahan tekanan oklusal, sehingga tidak menyebabkan fraktur, retakan dan melengkungnya restorasi di bagian servikal. ${ }^{16-18}$

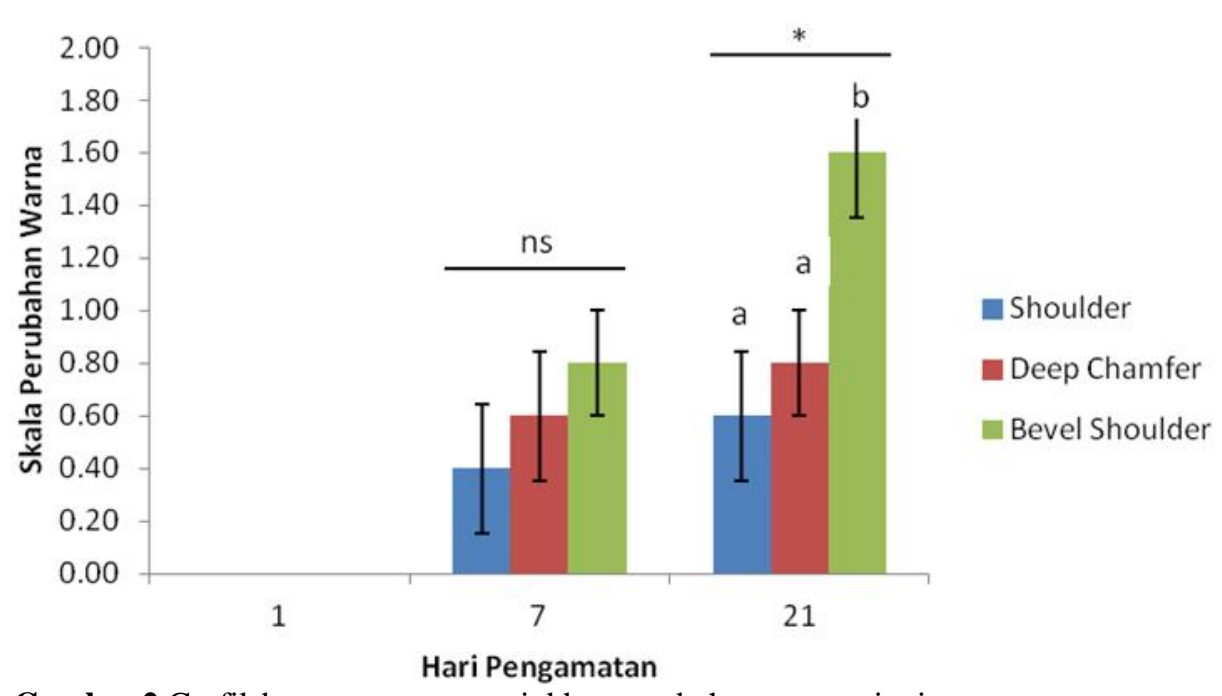

Gambar 2 Grafik batang yang menunjukkan perubahan warna gingiva pasca pemasangan mahkota PFM.

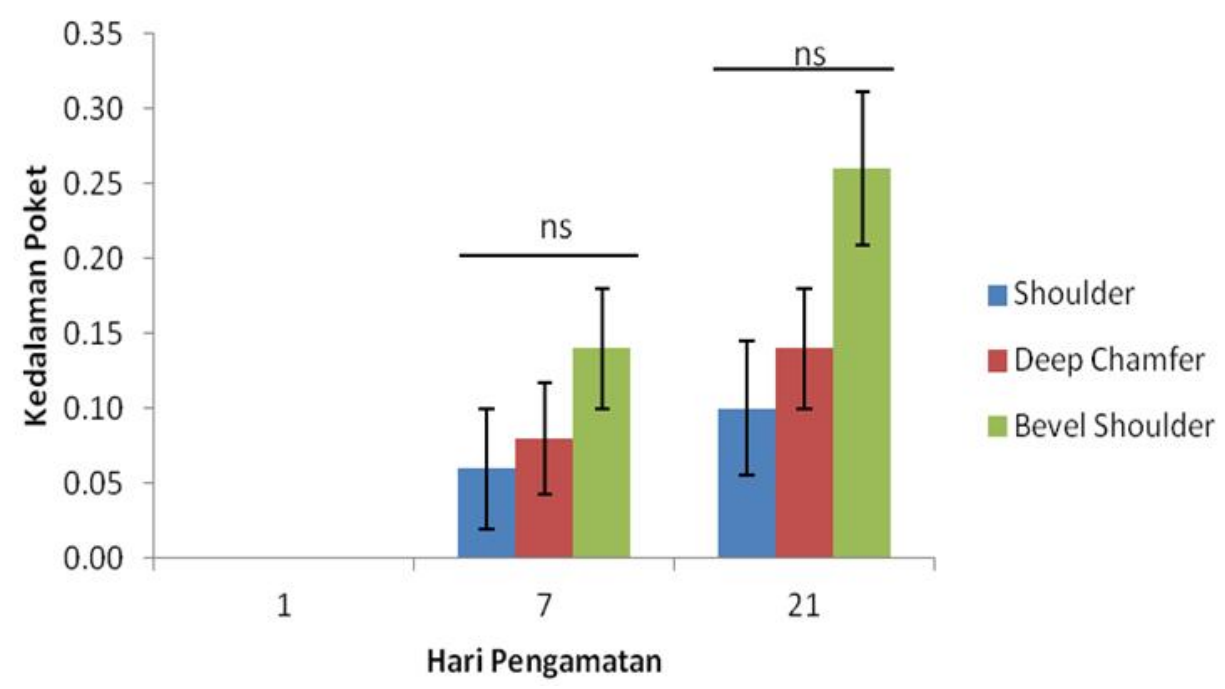

Gambar 3 Grafik batang yang menunjukkan hasil pengamatan kedalaman poket sebelum dan sesudah pemasangan mahkota PFM 


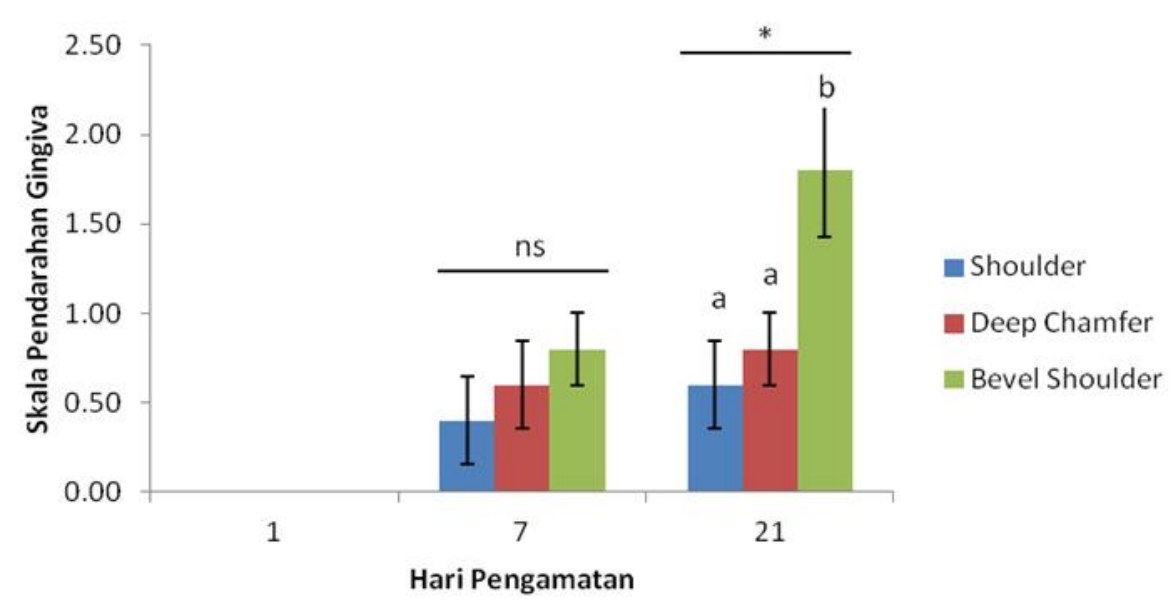

Gambar 4 Grafik batang menunjukkan pendarahan gingiva pasca pemasangan PFM

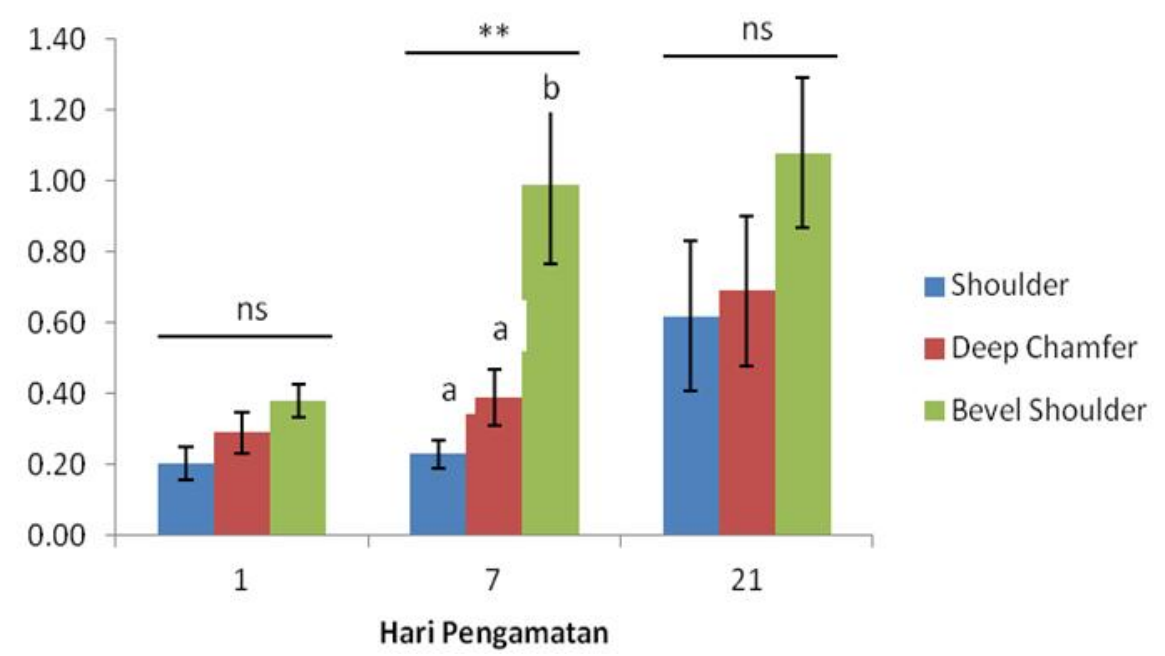

Gambar 5 Grafik batang menunjukkan jumlah koloni bakteri pasca pemasangan mahkota PFM

Hasilpenelitian ini menunjukkan bahwa bentuk akhiran preparasi tepi servikal shoulder mempunyai adaptasi tepi yang baik. Hal ini terlihat pada gambar 5 bahwa bentuk preparasi akhiran servikal shoulder $d$ ari hari pertama sampai dengan hari ke-21 setelah pemasangan mahkota PFM tidak memperlihatkan peningkatan jumlah koloni bakteri yang bermakna ( $>0,05)$. Sedangkan bentuk akhiran tepi preparasi servikal bevel shoulder dan deep chamfer memiliki adaptasi tepi servikal yang kurang baik, sebagaimana ini dapat terlihat pada gambar 5, sehingga terjadi perubahan jumlah kolonibakteri yang bermaknapada bentuk akhiran preparasi bevel shoulder dan deep chamfer $(\mathrm{p}<0,05)$; sebagai akibat adanya celah tepi yang merupakan tempat bagi plak gigi untuk tumbuh dan berkembang.

Banyak riset menunjukkan bahwa Streptococcus mutans yang asalnya dari plak gigi, adalah penyebab utama gingivitis, yang diketahui dengan melihat peningkatan koloninya pada pemeriksaan kultur sel.
Bentuk akhiran preparasi bevel shoulder dan deep chamfer pada penelitian ini merupakan bentuk preparasi akhiran tepi yang dapat meningkatkan jumlah koloni bakteri, karena mempunyai adaptasi tepi restorasi yang kurang adekuat jika dibandingkan dengan desain preparasi shoulder yang mempunyai kerapatan tepi yang beradaptasi rapat pada sekeliling bagian tepi servikal restorasi, sehingga plak gigi tidak dapat hidup dan berkembang di daerah tersebut.

Perubahan perdarahan saat melakukan probing pada penelitianiniterjadipada desain preparasi bevel shoulder dan deep chamfer, karena adanya reaksi peradangan. Proses peradangan meliputi masuknya sel darah putih, komplemen, antibodi, dan plasma protein ke tempat terjadinya infeksi atau jejas dengan tujuan mempertahankan diri. ${ }^{19}$ Radang merupakan reaksi tubuh terhadap invasi organisma mikro atau benda asing, dan rusaknya jaringan. Untuk merusak benda asing tersebut, tubuh mengerahkan elemenelemen sistem imun ke daerah radang. ${ }^{20}$ 
Hasil penelitian ini menginformasikan bahwa terjadi perubahan kedalaman poket yang bermakna pada bentuk akhiran preparasi bevel shoulder dan deep chamfer $(\mathrm{p}<0,05)$ dibandingkan dengan bentuk shoulder $(\mathrm{p}>0,05)$. Hal tersebut disebabkan karena gingiva pada bentuk akhiran bevel shoulder dan deep chamfer mengalami pembengkakan sebagai hasil reaksi peradangan. Pembengkakan pada gingiva dapat menyebabkan perubahan kedalaman poket.

Dari hasil penelitian penelitianini, menunjukkan bentuk preparasi tepi bevel shoulder memberikan dampak yang paling bermakna terhadap kejadian gingivitis dibandingkan jenis desain shoulder dan deep chamfer.

\section{DAFTAR PUSTAKA}

1. Machmud E, Roswita. Kadar TNF-a dan IL-B cairan sulkus gingiva setelah pemasangan mahkota akrilik. J Dentofasial 2007; 6(1): 58-60.

2. Chiche GJ. Mahkota keramik suatu prosedur klinis dan estetik. Alih bahasa: Hutauruk C. Editor: Yuwono L. Jakarta: Wijaya Medika; 1995. p.108-15

3. Waila S, Thomas J, Sandhu H. Restoring esthetics with metal-free ceramics. J Can Dent Assoc 2009; 75(5): 353-5.

4. Mc Laren EA, Vigoren G. Crown considerations, preparations, and material selection for esthetic metal-ceramic restoration. Esthetic Technique 2001; 1(4): 3-9.

5. Mc Laren EA, Vigoren G. Preparations and controlling tooth reduction part 2: Crowns and fixed partial dentures. Inside Dent 2007: 88-90.

6. Rimmer S. Modern dental ceramics: An overview. Int Dent SA 8(4): 32-40.

7. Kelly JR. Ceramics in restorative and prosthetic dentistry. Ann Rev Mater Sci 1997: 443-68.

8. Al-Dwairi ZN, Al-Hiyasat AH, Aboud H. Standards of teeth preparations for anterior resin bonded all-ceramics crowns in private dental practice in Jordan. J Appl Oral Sci 2010: 370-7.

9. MacLean S. Treatment using a porcelain-fused-to-titanium crown. Nova Scotia: Faculty Division of Dental Implantology Elective, Dalhausie Dental School halifax; 2009. p.1-4.

10. Anusavice KJ. Philips' science of dental materials. $11^{\text {th }}$ Ed. Philadelphia: WB Saunders; 2003. p.655-9.

11. Boeckler AF, Stadler A, Satz JM. The significance of marginal gap and overextension measurement in the evaluation of the fit of complete crowns. J Contem Dent Pract 2005; 6(4): 1-3.

12. Pitt Ford TR. Restorasi gigi. Edisi 2. Alih Bahasa Sumawinata N. Jakarta: EGC; 1993. p.148-57.

13. Manicone PF, Iommetti PR, Raffaelly L. An overview of zirconia ceramics: Basic properties and clinical applications. Institute of Clinical Dentistry, Rome, Italy; 2007:35: 819-26.

14. Alex G. Preparing porcelain surfaces for optimal bonding. Functional Esthetics and Restor Dent :2(1): 38-49.

15. Mc Laren EA.All ceramic alternatives to conventional metal ceramic restorations. Compendium 1998:19(3):307-20

16. Shillingburg HT, Hobo S, Whitsett LD, Jacobi R, Brackett SE. Fundamentals of fixed prosthodontics. $3^{\text {rd }}$ Ed. Chicago: Quintessence Pub.; 1997. p.119-212.

17. Denry I, Holloway JA. Ceramics for dental applications: A review. J. Mater 2010; 3: 351-68.

18. Pilatthadka S, Vahalova D, Vosahlo T. The zirconia: A new dental ceramic material. An overview. Prague: The Karolinum Press; 2007. p.1-12.

19. Cilmiaty R. Kelainan jaringan penyangga gigi. Diakses pada 29 Desember 2012. Available from: http://cilmiaty. blogspot.com/2009/04/kelainan-jaringan-penyangga-gigi-by.html.

20. Zarone F, Apicella D, Sorentino R, Ferro V, Aversa R, Apicella A. Influence of tooth preparation desin on stress distribution in maxillary central incisors restored by means of alumina porcelain veneers: A 3D-finite element analysis. J Dent Mater 2005; 21: 1178-88. 